DOI https://doi.org/10.18551/rjoas.2017-03.16

\title{
THE EFFECTS OF TRANSFORMATIONAL LEADERSHIP-STYLE AND COMPENSATION TOWARDS WORK SATISFACTION AND ORGANIZATIONAL COMMITMENT: A STUDY AT PG MODJOPANGGOONG IN TULUNGAGUNG, INDONESIA
}

\author{
Sudirman Farid Ardhy \\ Postgraduate Program of Faculty of Administration Science, \\ University of Brawijaya, Indonesia \\ E-mail: faridardhysudirman@gmail.com \\ Raharjo Kusdi, Utami Hamidah Nayati \\ Faculty of Administration Science, University of Brawijaya, Indonesia \\ E-mail: kusdi@ub.ac.id, hamidah fia@ub.ac.id
}

\begin{abstract}
An organization requires figure of a leader who is able to transfer knowledge, skills, and ability to manage the human resources to achieve shared goals. The aims of this research were to analyze and explain: 1) the effect of transformational leadership style on work satisfaction, 2) the effect of compensation on work satisfaction, 3) the effect of transformational leadership style on organizational commitment, 4) the effect of compensation on organizational commitment, and 5) the effect of work satisfaction on organizational commitment. This research would analyze and explain the relationship between transformational leadership style (X1), compensation (X2) on work satisfaction (Y1) and organizational commitment (Y2), therefore this research was an explanatory research. The results obtained were: 1) Leadership style significantly affected work satisfaction with an effect value of 0,659 or $65,9 \%$; 2 ) Compensation significantly affected work satisfaction with an effect value of 0,232 or $23,2 \%$; 3 ) Leadership style significantly affected the organizational commitment with an effect value of 0,837 or $83,7 \%$; 4) Compensation significantly affected work satisfaction with an effect value of 0,077 or $7,7 \% ; 5$ ) Work satisfaction was significantly affect the organizational commitment with an effect value of 0,107 or $10,7 \%$. Generally, it can be concluded that transformational leadership style and compensation affect significantly on work satisfaction and organizational commitment of PG Modjopanggoong employees.
\end{abstract}

\section{KEY WORDS}

Compensation, leadership style, transformation, organization, organizational commitment, works satisfaction.

An organization requires figure of a leader who is able to transfer knowledge, skills, and ability to manage the human resources to achieve shared goals. The nature of leadership is facilitating individual development to realize their potency (Tulus, 2002). Leadership encompasses aspect of triggering, mobilizing, and influencing the subordinates or the members of an organization to perform tasks in order to achieve shared goals. The role of a leader or leadership in an organization or company consists of three aspects: 1) interpersonal role; 2) informational role; and 3) taking-decision role.

Compensation is a factor which can motivate the workers to work optimally in order to achieve the goals of the company. The compensation should cover the needs of the workers, by the fact that the desire of fulfilling the needs is one of the factors which motivate the workers to perform their tasks.

According to Hasibuan (2002:135), compensation or re-compensation is generally for the concern of the company and the workers. The concern of the company by giving compensation is that the company would obtain a return. A worker who receives compensation according to what he has done for the company would be more motivated to 
work hard and would be satisfied. That feeling of satisfaction would affect the workers to advance their commitment for the company.

Commitment as an attitude which reflects the loyalty of the workers to the company and as a continuous progress in which the members of the organization express their concern towards the success and continuous advancement of the organization (Luthan, 2006). If the workers have a high organizational-commitment, they would not have any desire to leave the organization (Mowday, Porter \& Steers, 1983).

The rapid existence of imported sugar in 1999-2000 encouraged the government to initiate policies to impede the flow of the imported sugar to the country. The majority of sugar industries in Java are stated-owned enterprises, the manufacturing factories are relatively old and operated with less-efficient performance, and the raw material is obtained from the cultivation of the irrigated farm. However, in the regions out of Java, for instance in Lampung, the sugar industries are in the form of new factories which are established by private owner in a big scale, the material is obtained from their own sugar-cane field in a dry field, and the factories are operated with relatively efficient performance based on international standard (Arifin, 2008).

Furthermore, the managerial level of the private companies is demanded to produce high profit for the company, while stated-owned enterprises have no demand of how big the target that should be achieved. This huge difference of the sugar production between stateowned enterprises and private companies made the competition of sugar industries higher, but the sugar production of state-owned enterprises kept decreasing from time to time. At that time, the government made some policies to improve the productivity of sugar industries. Unfortunately, it did not work much because the policies were not well-coordinated, and the leadership style existed in the management of the factory under state-owned enterprises were still in the form of conventional leadership.

This research was conducted at PG Modjopanggoong in the regency of Tulungagung which has high production of sugar and is one of the biggest sugar suppliers in East Java. The factory has big numbers of workers which are categorized into two: permanent and nonpermanent workers which consist of seasonal and campaign workers. PG Modjopanggoong was established since 1852. Based on the observation, the researchers obtained the following facts.

PG Modjopanggoong is operated under state-owned enterprise (BUMN) from PTPN X, however, as what happen in many sugar factories, PG Modjopanggoong is hindered by the main challenge in which there lacks of coordination from the leader to the subordinates, which makes work satisfaction of the workers very low. It could directly affect the workers' organizational commitment to decrease and become low. Related to the theories, conventional leadership-style belongs to authority theory (authority compliance) by Robert R. Blake and Jane S. Mourton (1985), in which this theory describes a leader which prioritize the result or target but pay less attention to the workers, except their engagement in finishing their tasks.

Based on the study on the background of this research and the information from previous researches, the researcher was encouraged to conduct a research with the same variables, about the effects of transformational leadership-style and compensation towards work satisfaction and organizational commitment. The objects of the study were the workers of PG Modjopanggoong who had never been participated as the objects of previous studies. The results of the research were expected to develop and strengthen the theories on the effects of research variables.

The research problems were as follows: 1) does the transformational leadership-style significantly affect work satisfaction?, 2) does the compensation significantly affect work satisfaction?, 3) does the transformational leadership-style significantly affect organizational commitment?, 4) does the compensation significantly affect organizational commitment?, 5) does the work satisfaction significantly affect organizational commitment?

The aims of this research were to analyze and explain: 1) the effects of transformational leadership-style towards work satisfaction, 2) the effects of compensation towards work satisfaction, 3) the effects of transformational leadership-style towards 
organizational commitment, 4) the effects of compensation towards organizational commitment, 5) the effects of work satisfaction towards organizational commitment.

\section{LITERATURE REVIEW}

Transformational Leadership-Style. Leadership-style is a behavior or method which is chosen and used by leaders to affect minds, feelings, attitude, and behavior of their organization members or workers (Nawawi, 2003).

According to Rivai (2004), leadership-style is a comprehensive pattern of a leader's acts, both visible and invisible acts to their subordinates. Leadership style describes consistent combination of philosophy, skills, characters, and attitude which constitute someone's behavior.

Transformational leadership is an ability to transfer support and motivate their members to achieve greater result based on what is planned and as an internal return (Gibson, 1997:86). Bass and Avolio (1993) state that transformational leaders always demonstrate visions and missions to support the inspirations of their subordinates so that they can improve their performance to achieve the goals. In this case, the workers would feel convinced, amazed, and loyal to their leaders so that they are more motivated to achieve the goals of the organization.

Compensation. Daft (2002) defines compensation as all monetary paying and all goods or commodities which are utilized as the substitution of money to give rewards to the workers. According to Wibowo (2010), compensation is a con achievement towards the use of effort or service from the workers. Compensation is the number of packages which is provided by the organization to the workers as a return of the use of their manpower. There are two categories of compensation: 1) financial compensation, 2) non-financial compensation.

Work Satisfaction. Robbins (2006) mentions that work satisfaction is defined as a positive feeling about someone's job as a result of their characteristics evaluation. Luthan (2006) states that work satisfaction is related to some main aspects: a) Work satisfaction cannot be seen, but its existence can be predicted because it is related to emotion or the response of the workers from work situation that they encounter with. b) Work satisfaction is related to the conformity of work result and the workers' expectation. c) Work satisfaction is strongly related to some concerns: the work itself, promotion chance, salary, supervision, and co-workers.

Organizational Commitment. Organizational commitment is defined as "relative strength of an individual identification in an organization with their particular engagement" (Porter et al., 1974). Moreover, Porter et al. conclude that organizational commitment is characterized by: 1) particular belief and understanding of goals and values of an organization or occupation; 2) someone's strong desire to optimize their effort for the concern of the organization or occupation, and 3) someone's strong desire to maintain their organizational membership.

H1: Transformational leadership-style significantly affects work satisfaction.

$\mathrm{H} 2$ : Compensation significantly affects work satisfaction.

H3: Transformationalleadership-style significantly affects organizational commitment.

H4: Compensation significantly affects organizational commitment.

H5: Work satisfaction significantly affects organizational commitment.

\section{METHODS OF RESEARCH}

Based on the concept of research, this research analyzed and explained the relationship of transformational leadership-style (X1), compensation (X2) towards work satisfaction (Y1) and organizational commitment (Y2). Therefore, this research was categorized as explanatory research.

The setting of this research was at PG Modjopanggoong in $\mathrm{Km} .1$, the regency of Tulungagung, East Java. The researcher conducted direct research to the workers of PG 
Modjopanggoong. The population was all of the workers of PG Modjopanggoong (600 workers).

\section{DATA ANALYSIS}

Test for Linearity. The test on SPSS using Test for Linearity with level of significance 0.05. The two variables had a relationship if the significance (linearity) was less than 0.05 .

Test for Normality. Test for normality was utilized to identify whether the data distribution of independent variable and dependent variable was normal.

Descriptive-Statistic Analysis. Descriptive-statistic analysis was aimed to identify frequency of distribution of respondents' responses from the questionnaire.

Inferential-Statistic Analysis. This statistic analysis was utilized to analyze sample data and the result was applied to the population. Inferential analysis which was used in this research was path analysis.

$$
\begin{gathered}
Y_{1}=p y_{1} x_{1} X_{1}+p y_{1} x_{2} X_{2}+p y_{1} \cdot \varepsilon_{1} \\
Y_{2}=p y_{2} X_{1} X_{1}+p y_{2} x_{2} X_{2}+p y_{2} y_{1} Y_{2} \cdot \varepsilon_{2}
\end{gathered}
$$

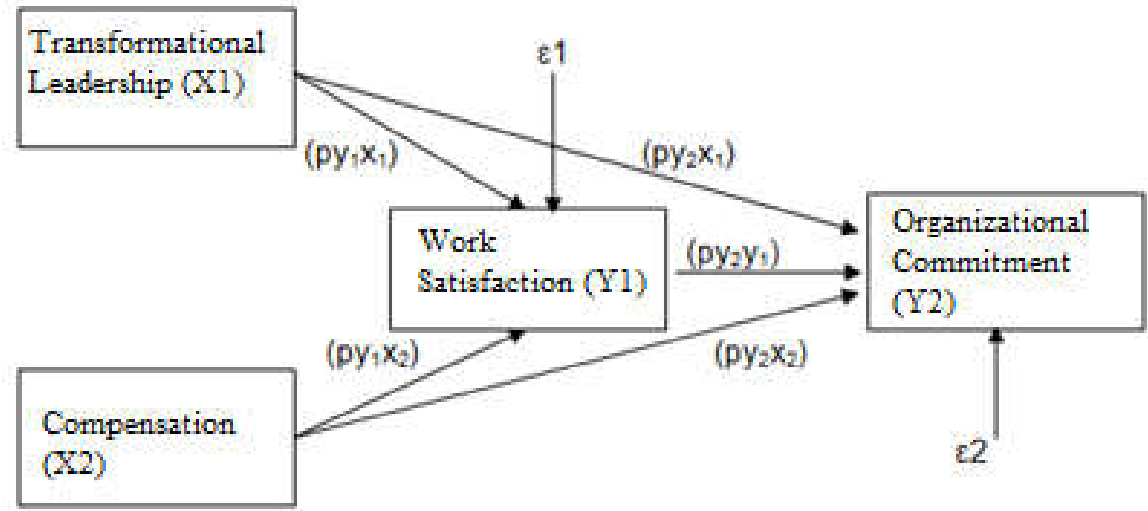

Figure 1 - Path Diagram

\section{RESULTS AND DISCUSSION}

Hypothesis $\mathrm{H} 1$ stated that there was significant effect of transformational leadershipstyle towards work satisfaction. The path coefficient on this relationship was 0.659 with significance ( $\mathrm{sig}, \mathrm{t}=0.000$ ), which could be concluded that the data supported hypothesis H1. Good transformational leadership-style enhances work satisfaction.

Hypothesis $\mathrm{H} 2$ stated that there was significant effect of compensation towards work satisfaction, the path coefficient was 0.232 with significance (sig, $t=0.000$ ). It meant that the result supported hypothesis $\mathrm{H} 2$, awarding a better compensation would enhance work satisfaction among the workers.

Hypothesis $\mathrm{H} 3$ stated that there was significant effect of transformational leadershipstyle towards organizational commitment. The path coefficient of this relationship was 0.837 with significance ( $\mathrm{sig}, \mathrm{t}=0.000$ ), which could be concluded that the result supported hypothesis H3. Good transformational leadership-style could enhance organizational commitment of the workers.

Hypothesis $\mathrm{H} 4$ stated that there was significant effect of compensation towards organizational commitment. The path coefficient was 0.777 with significance (sig, $t=0.036$ ), it meant that the result supported hypothesis $\mathrm{H} 4$, giving good compensation could advance organizational commitment of the workers.

Hypothesis H5 stated that there was significant effect of work satisfaction towards organizational commitment. The path coefficient was 0.107 with significance $(\mathrm{sig}, \mathrm{t}=0.035$ ), 
so that the result of the research supported hypothesis $\mathrm{H} 5$, in which work satisfaction could improve organizational commitment of the workers.

The Effect of Transformational Leadership-Style towards Work Satisfaction. The result of path analysis demonstrated that transformational leadership-style (X1) significantly affected work satisfaction (Y1) with significance value 0.000 which was less than $\alpha(0.05)$. The improvement in the implementation of transformational leadership-style would result to the improvement of work satisfaction of the workers. On the other side, leadership style significantly affected work satisfaction with the value of effect 0.659 or $65.9 \%$.

The Effect of Compensation towards Work Satisfaction. The result of path analysis showed that compensation (X2) significantly affected work satisfaction (Y1) with significance value 0.003 which was less than $\alpha(0.05)$. The higher compensation given by the company would result higher work satisfaction of the workers. On the other side, compensation significantly affected work satisfaction with value of effect 0.232 or $23.2 \%$.

The Effect of Transformational Leadership-Style towards Organizational Commitment. The result of path analysis demonstrated that transformational leadership-style (X1) significantly affected organizational commitment (Y2) with significance value 0.000 which was less than $\alpha(0.05)$. On the other side, transformational leadership-style significantly affected organizational commitment with value of effect 0.837 or $83.7 \%$.

The Effect of Compensation towards Organizational Commitment. The result of path analysis demonstrated that compensation (X2) significantly affected organizational commitment (Y2) with significance value 0.036 which was less than $\alpha(0.05)$. On the other side, compensation significantly affected work satisfaction with value of effect 0.077 or $7.7 \%$.

The Effect of Work Satisfaction towards Organizational Commitment. The result of path analysis demonstrated that work satisfaction (Y1) significantly affected organizational commitment (Y2) with significance value 0.035 which was less than a (0.05). On the other side, compensation significantly affected work satisfaction with value of effect 0.107 or $10.7 \%$.

\section{CONCLUSIONS AND SUGGESTIONS}

These followings are the conclusions of the research:

1. Transformational leadership-style significantly affected work satisfaction of the workers of OG Modjopanggoong. It explained that better transformational leadershipstyle would improve work satisfaction among the workers.

2. Compensation significantly affected work satisfaction of the workers of PG Modjopanggoong. The higher compensation given by the company would increase work satisfaction of the workers of PG Modjopanggoong.

3. There was significant effect of transformational leadership-style towards organizational commitment of the workers of PG Modjopanggoong. Good implementation of transformational leadership-style would encourage the workers to be more committed towards the organization of PG Modjopanggoong.

4. The compensation received by the workers of PG Modjopanggong significantly affected organizational commitment. If the workers felt that the compensation increased, it would result the enhancement of organizational commitment.

5. Significant effect existed in work satisfaction towards organizational commitment of the workers of PG Modjopanggoong as well. The improvement of work satisfaction would advance organizational commitment.

From the results of the research, the researcher identified that transformational leadership-style in PG Modjopanggoong transferred positive and significant effect towards the variables of work satisfaction and organizational commitment. Therefore, it should be maintained by the fact that it held direct effect towards work satisfaction and organizational commitment of the workers. This meant that the workers approved transformational leadership-style in the form of ideal effect, motivation, and intellectual stimulus given by the leaders and also considerations which are matched to the problems existed in PG Modjopanggoong. 
PG Modjopanggoong should pay attention to the aspects related to work satisfaction of the workers. According to the majority of respondents or almost all of the workers who have been working in PG Modjopanggoong for a long time, giving rewards, supports, and another bonus in greater amount are some aspects which could affect work satisfaction so that they could enhance their commitment towards the company. The duration of their working time could be utilized as the level of loyalty of a worker towards the company, including the workers of PG Modjopanggoong who have been working in the company for a long time.

Developing another independent variable could affect organizational commitment. For example, the performance of the workers, motivation, or the culture of the organization. This case is in line with some references from previous researches which are utilized as a reference and comparison in this research.

\section{REFERENCES}

1. Bass, B.M. (1990). From Transactional to Transformational Leadership: Learning to Share the Vision Organizational Dynamics. Dalam Steers, R.M., Porter W., dan Bigley, G.A. (Eds). 1996. Motivation and Leadership at Work Sixth Edition, New York: The McGraw Hill companies, 628-640.

2. Bass, B.M. and Avolio, B.J. (1993).Transformation Leadership and Organizational Culture.Journal of Management, hlm.639-703.

3. Daft, Richard L. 2002. Manajemen, Edisi Kelima, Jilid I. Jakarta : Erlangga.

4. Gibson, L. James, John M. Ivancevich and James H. Donnelly, Jr. (2006).Organisasi: Perilaku, Struktur, Proses. Jakarta: PT GeloraAksaraPratama.

5. Hasibuan, Malayu S.P. 2002. Organisasi dan Motivasi. Edisi Revisi. Jakarta : Bumi Aksara.

6. Luthan, Fred. 2006. Perilaku Organisasi, Alih Bahasa V.A Yuwono, dkk, Edisi Bahasa Indonesia. Yogyakarta: Andi.

7. Mowday, R.T., Porter, L.W., and Steers, R. 1983. Organizational Linkages : The Psychology of Commitment, Absenteeism, and Turnover. San Diego, California: Academic Press.

8. Nawawi. 2003. Sumber Daya Manusia untuk Bisnis yang Kompetitif. Jakarta : Bumi Aksara.

9. Rivai, Veithzal. 2009. Manajemen Sumber Daya Manusia untuk Perusahaan: Dari Teori ke Praktik. Jakarta: Rajawali Pers.

10. Robbins, Stephen. P. 2006. Perilaku Organisasi (alih bahasa Drs. Benjamin Molan), Edisi Bahasa Indonesia. Klaten : PT Intan Sejati.

11. Tulus, Moh. Agus. 2002. Manajemen Sumber Daya Manusia: Buku Panduan.

12. Wibowo. 2010. Budaya Organisasi. Jakarta : Rajawali Pers. 